\title{
The Land Rights Which Can Be Given On The Land Management System
}

\section{Carrissa Shannon Lie $^{*}$ and Yohanes Kristian Pranata**)}

*) Faculty of Law, Universitas Airlangga, Indonesia, E-mail: carrissa.annon.lie2020@fh.unair.ac.id

${ }^{* *}$ Faculty of Law, Universitas Airlangga, Indonesia, E-mail: yohanes.kristian.pranata2020@fh.unair.ac.id

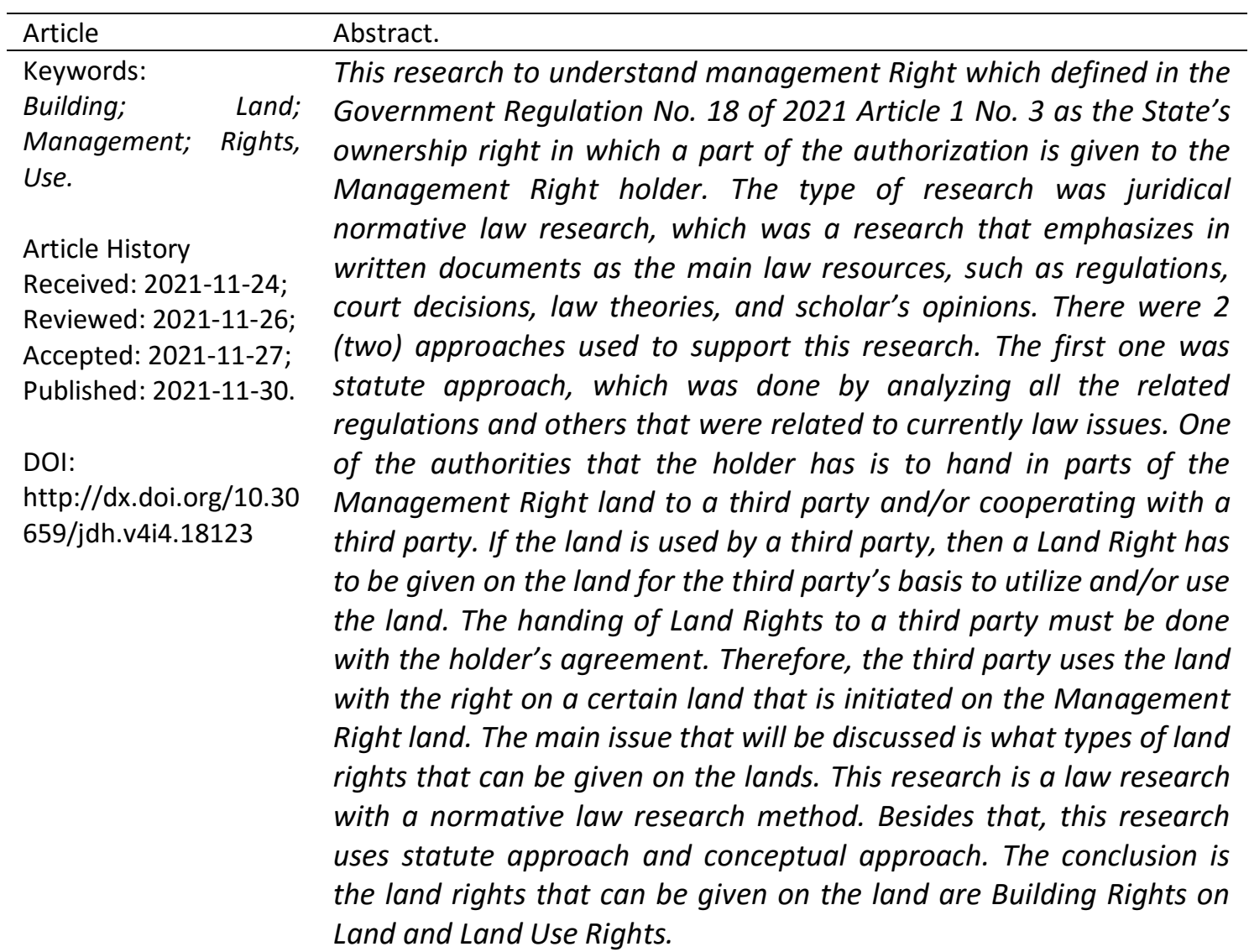

(C)2021; This is an Open Access Research distributed under the term of the Creative Commons Attribution License (https://Creativecommons.org/licences/by/4.0), which permits unrestricted use, distribution, and reproduction in any medium, provided the original works is properly cited

\section{Introduction}

Act No. 5 of 1960 Article 2 verse (1) concerning Basic Agrarian Law (UUPA) regulates that on the requirements of Constitution Article 33 verse (3) and things that are meant in Article 1, earth, water, and airspace, including the natural resources inside is owned by the State on the highest level. Article 2 verse (1) is called the State's Ownership Right, which is elaborated further that it gives 3 (three) authorities to the State, which are:

- to regulate and administer the allocation, use, supply, and maintenance of the earth, water, and airspace; 
- to determine and regulate legal relationships between people and the earth, water, and airspace;

- to determine and regulate legal relationships among people as well as legal acts concerning the earth, water, and airspace.

Basic Agrarian Law Article 2 verse (4) then regulates that the State's Ownership Rights above can be authorized to autonomous areas and traditional societies for the execution, if necessary and does not violate national interests based on the Government Regulations. Article 2 verse (4) is a form of authorization owned by the State. It is regulated in Basic Agrarian Law Article 2 verse (2) for autonomous areas or traditional societies, but only partially. If it is authorized wholly, it will cause the existence of a "State inside a State".

Government Regulation No. 18 of 2021 concerning Management Rights, Land Rights, Apartment Units and Land Registration (PP 18/2021) in Article 1 verse (3) defines Management Right as the right to own from the State in which the authorization is partially given to the Management Right holder. According to Urip Santoso, there are 3 (three) authorities that are given to a Management Right holder towards the land, which are:

- Planning the land's allocation and use;

- Using the land as a need to execute duties;

- Handing parts of the Management Right land to a third party and/or cooperating with a third party. ${ }^{1}$

The authority that becomes the base for this journal's discussion is the third authority, which is handing parts of the Management Right land to a third party and/or cooperating with a third party. The land can be used by the holder himself, herself, or themselves to execute his, her, or their duties or it can be used for a third party with the holder's agreement. The basis for a third party to use tha land is by having the land right given on the land to the third party. The land right is later held by the third party and with it as the basis, the third party can use the land according to the allocation of the right given to the third party on the land.

\section{Research Methods}

The type of research was juridical normative law research, which was a research that emphasizes in written documents as the main law resources, such as regulations, court decisions, law theories, and scholar's opinions. There were 2 (two) approaches used to support this research. The first one was statute approach, which was done by analyzing all the related regulations and others that were related to currently law issues ${ }^{2}$, while the second one was conceptual approach, which was done by studying perspectives and doctrines in the law field ${ }^{3}$. This research used 2 (two) law resources, which were primary resources and secondary resources. Primary resources were law sources that were bound in the forms of regulations, specifically those that arranged

\footnotetext{
${ }^{1}$ Urip Santoso. (2017). Hukum Agraria Kajian Komprehensif. Jakarta: Kencana. p.191. (Urip Santoso I)

${ }^{2}$ Peter Mahmud Marzuki. (2017). Penelitian Hukum. Jakarta: Kencana. p.137.

${ }^{3}$ Ibid., p.138.
} 
or related to the main problems discussed in this research, while secondary resources were law sources that gave explanation concerning the primary law resources ${ }^{4}$.

The primary resources used in this research were:

- Act No. 5 of 1960 concerning Basic Agrarian Law;

- Government Regulation No. 18 of 2021 concerning Management Right, Land Right, Apartment Unit and Land Registration;

- Agrarian Minister Regulation No. 9 of 1965 concerning the Execution of Ownership Right of the State's Land Convertion and Regulations Concerning Future Decisions;

- Agrarian Minister/Head of National Land Agency Regulation No. 4 of 1998 concerning Guidelines in Establishing Income in Giving State Land Right.

The secondary resources were law sources in the forms of publications that explained primary law resources, such as literatures, journals and other non-official media ${ }^{5}$. The procedure in collecting law resources, both primary and secondary resources, that were used in this research was by doing literature study and searching data that were collected by inventarization procedure regulations identification, as well as classification and systematization of the law resources. The existing law resources would be selected based on the law issues that would be analysed, which were land laws and civil laws. Analysis towards the existing law resources, both primary and secondary law resources that were collected, was done by systematic and grammatical interpretation was one of the interpreting methods done by interpreting the laws that were linked between one article to another in the same regulation or with another regulation ${ }^{6}$. This method had to be used because most of the regulations were always related to other regulations. Only very few regulations that stood alone and was not linked to the whole regulation system. The regulations used in this research were every regulation related to land, which were Basic Agrarian Law, Government Regulation 18/2021, and Agrarian Minister Regulation No. 4 of 1998.

Grammatical interpretation was one of the ways to interpret by interpreting laws according to their normalization. In making the regulations language was the only tool that was used by the maker of the law to express his or her desire, but sometimes he or she could not arrange the words correctly ${ }^{7}$. Because of that, the writer attempted to find the desired words by explaining them according to the language, word organization, and the content of the regulations related to land.

\section{Results and Discussion}

\subsection{Land Ownership Right Basic Agrarian Law (UUPA)}

One of the things regulated by Act No. 5 of 1960 concerning Basic Agrarian Law (UUPA) as the national land law is land ownership right. According to Boedi Harsono, land ownership right has a set of authorities, obilgations, and/or restrictions for the holder to do something towards the land which is under his or her right. The things

\footnotetext{
${ }^{4}$ Ibid., p.181.

${ }^{5}$ Ibid., p.195.

${ }^{6}$ Yudha Bhakti Ardhiwisastra. (2012). Penafsiran dan Konstruksi Hukum. Bandung: PT. Alumni. p.11.

${ }^{7}$ Ibid., p.9.
} 
that can, must, or must not be done, which are the content of ownership right become the criterium among the land ownership rights that are regulated in Land Law. ${ }^{8}$

In land ownership right there are hierarchies, which are:

- Indonesian Nation's Land Right (Article 1 of Basic Agrarian Law);

- The State's Land Ownership Right (Article 2 of Basic Agrarian Law);

- Traditional Society's Customary (Ulayat) Right (Article 3 of Basic Agrarian Law);

- Personal Right, which include: Land Right; Ownership Right's Land Charity; Mortgage Right; Apartment Unit Ownership Right.

Land ownership right can be private, which means to have, and public, which means to regulate and to decide. Included as public land ownership right is the State's Land Ownership Right, while the private one is land right. ${ }^{9}$

Public land ownership right, which is the State's Land Ownership Right, is regulated in Basic Agrarian Law Article 2 and is sourced from Indonesian Nation's Land Right. In Basic Agrarian Law Article 2, the authorities that the State have are:

- to regulate and administer the allocation, use, supply, and maintenance of the earth, water, and airspace;

- to determine and regulate legal relationships between people and the earth, water, and airspace;

- to determine and regulate legal relationships among people as well as legal acts concerning the earth, water, and airspace.

According to Muhammad Bakri, based on the nature and principle, the State's authority which comes from the State's Land Right is in the hands of Central Government. ${ }^{10}$

Basic Agrarian Law Article 2 Verse (4) then further regulates that the State's Ownership Right can be administered to autonomous areas and traditional societies in its execution, if necessary and not violating national interests based on the Government Regulations.

From there it can be seen that autonomous areas (now local government), can only have that authority if there is a delegation of authority in executing the State's Land Ownership Right from the Central Government to Local Government. ${ }^{11}$

The term Management Right is not known in the Basic Agrarian Law, but it only uses the word "management" in the General Elucidation No. II Point 2 of the Basic Agrarian Law: "the State can grant such land to an individual or corporate body under a certain right, e.g. Ownership Right, Cultivating Right, Building Right, or Use Right according to the allotment or the need or grant it to a certain Power Body [e.g. a Department, Service or Autonomous Region] under a right of management for use by the latter to facilitate the implementation of its duties."

\footnotetext{
8 Boedi Harsono. (2007). Hukum Agraria Indonesia: Sejarah Pembentukan Undang-Undang Pokok Agraria, Isi dan Pelaksanaannya. Jakarta: Djambatan. p.24.

${ }^{9}$ Urip Santoso. (2012). Eksistensi Hak Pengelolaan dalam Hukum Tanah Nasional. Jurnal Mimbar Hukum, 24.2, 187 - 375. p.276. (Urip Santoso II)

${ }^{10}$ Muhammad Bakri. (2007). Hak Menguasai Tanah Oleh Negara (Paradigma Baru untuk Reformasi Agraria). Jakarta: Citra Media. p.37.

${ }^{11}$ Ibid., p.37.
} 
A.P. Parlindungan states that the term Management Right is taken from Dutch, which is Beheersrecht that means Ownership Right if translated to Indonesian. ${ }^{12}$ Ownership Right alone is regulated in the Government Regulation No. 8 of 1953 concerning Ownership of the State's Lands (PP 8/1953). According to Maria S.W. Sumardjono, this law regulates Management Right as an interpretation from Beheersrecht on the State's lands. The referred Ownership Right is ownership rights of the State's lands ${ }^{13}$.

The term Management Right first appears in the Agrarian Minister Regulation No. 9 of 1965 concerning the Execution of Ownership Right of the State's Land Convertion and Regulations Concerning Future Decisions (PMA 9/1965) ${ }^{14}$. Article 2 of this regulation regulates: "If the State's Land's Ownership Right that are given to departments, directorates, and autonomous states, besides being used for the importance of those instances, is also menat to be given with a right to a third party, then the right is converted into Management Right."

Government Regulation 18/2021 Article 1 Verse (3) gives the definition of Mnagement Right, which is an ownership right from the State which authorization is partially given to the Management Right holder. The definition of Management Right shows that Management Right is the State's Land Ownership Right as regulated in the Basic Agrarian Law Article 2 and it is not the land right which is mentioned in Basic Agrarian Law Article 4, Article 16 verse (1), and Article 53. However, management right is not purely the State's Land Ownership Right, but it is the authorization of the State's Land Ownership Right. ${ }^{15}$

The party that has Management Right is called Management Right Subject. According to Eman Ramelan, Management Right subjects or holders limited to the Governmnet's legal entity which is active both in public service and business, such as State-Owned or Local-Owned Corporation, and Limited Liability Company (LLC). ${ }^{16}$ Urip Santoso agrees and states that Management Right is given to the Government's legal entity that is active in public service or business that has a main duty and its function is related to land management. ${ }^{17}$ The Government Regulation 18/2021 Article 5 Verse (1) and its elucidation clarifies and emphasizes the Management Right subjects, which are:

- Central Government Instance;

- Local Government;

- State-Owned or Local-Owned Enterprise;

- State-Owned or Local-Owned Legal Entity, which is established by the Central of Local Government with public legal entity status;

\footnotetext{
${ }^{12}$ A.P. Parlindungan. (1994). Hak Pengelolaan Menurut Sistem Undang-Undang Pokok Agraria. Bandung: Mandar Maju. p.6.

${ }^{13}$ Urip Santoso II, Op.Cit, p.278

14 Urip Santoso. (2019). Pendaftaran dan Peralihan Hak atas Tanah. Jakarta: Kencana. p.114 (Urip Santoso III).

${ }^{15}$ Urip Santoso II, Op.Cit., p.280.

16 Eman Ramelan. (2000). Hak Pengelolaan Setelah Berlakunya Peraturan Menteri Negara Agraria/Kepala Badan pertanahan Nasional. Majalah YURIDIKA, 15.3. p.196.

${ }^{17}$ Urip Santoso I, Op.Cit., p.168.
} 
- Land Bank Corporation, which is a special entity (sui generis) which is an Indonesian legal entity that is formed by the Central Government that is given a special authority to manage lands; and

- Legal entity appointed by the Central Government, which is a legal entity that is tasked by the Central Government in order to develop certain areas such as authority entity.

Management Right Subjects have the authorization that is related to the land that they have. According to Urip Santoso, the existence of convertion from the State's Land Ownership Right to Management Right causes a transition in characteristics from the State's land ownership right which is publikrechtelijk (public) to a combination between publikrechtelijk and privatrechtelijk. The publikrechtelijk characteristics are seen from the subject's authority to plan the allocation and use of the land, while the privatrechtelijk characteristics are seen in the subject's authority to use the land as a need to execute duties, handing in parts of the land to a third party with a right over certain lands and accepting income, refund, and/or annual fee ${ }^{18}$.

Based on Government Regulation 18/2021 Article 7, the authorities given to the Management Right holders are:

- Planning the land's allocation, use, and utilization based on the spatial plan;

- Using and utilizing all or parts of the Management Right lands personally or cooperated with other parties; and

- Deciding the toll and/or annual fee from other parties based on the agreement.

According to Boedi Harsono, the authorities that stick to Management Right holders are as following:

- Planning the land's allocation and use;

- Using the land as a need to execute duties;

- Handing parts of the Management Right land to a third party and/or cooperating with a third party. ${ }^{19}$

The authority to hand in parts of the land to a third party cannot be done directly. There are conditions and procedures that just be fulfilled by the corresponding parties to do so.

Based on the guidelines of the Minister of National Affairs Regulation No. 1 of 1997 Article 3 verse (1) concerning Guidelines to Ask and Settle the Distribution of Rights on Parts of Management Right Lands as well as Its Registration, every distribution of land use must be done through the composing of a written agreement between Management Right holder with the corresponding third party. Article 3 verse (2) of the same regulation also regulates that the written agreement must at least mention several items, which are:

- The identities of the corresponding parties.

- Location, boundaries, and area of the aforementioned land.

- The type of use.

- Land right that is asked to be given to the corresponding third party and details concerning the time as well as possibilities to extend it.

\footnotetext{
18 lbid., p. 169.

${ }^{19}$ Boedi Harsono, Op.Cit., p.280.
} 
- The types of building that will be build on top of it and requirements concerning ownership of the buildings when the given land right expires.

- Amount of income and payment terms.

- Other terms which are necessary.

It needs to be understood that even though the guidelines in the Minister of National Affairs Regulation No. 1 Of 1997 Article 3 decides that the agreement between Management Right holder and the corresponding Third Party must be composed in a written form, it does not regulate the name and the type of agreement. According to Maria S.W. Sumardjono, the legal correlation between the Management Right Holder and the corresponding Third Party in terms of distributing land right to the third party is included in a written agreement, which is Letter of Land Use Agreement. ${ }^{20}$ In practice, the agreement between the Management Right Holder and the corresponding Third Party is known under several terms. Some of them are Land Use Agreement, Cooperative Agreement concerning Land Utilization for Building and Building of Shopping Center Hall, Distribution of Harbor Land Use Agreement, Industrial Land Use Agreement, and many more. ${ }^{21}$

In the of 1999, the regulation above was declared obsolete and substituted with the Agrarian Minister/Head of National Land Agency Regulation No. 9 Of 1999. It regulates that legal correlation concerning management right land use between the right's holder and the corresponding third party is done by Land Use Agreement, especially in Article 4 verse (2). The referred agreement can be made with notarial deed or signed deed as long as it fulfils the 4 terms for an agreement to be official as regulated in Article 1320 BW. ${ }^{22}$

Besides using the aforementioned agreement, Management Right land use by the third party can be composed in a Built, Operate, Transfer (BOT) Agreement. According to Maria S.W. Sumardjono, what is meant by BOT Agreement is a two-sided agreement, in which the first party hands in the land use to a third party for structures bulding, and the second party may manage or operate the structures in a certain period with giving or not giving a fee to the first party. ${ }^{23}$ In this agreement, the second party must return the land as well as the structures on it to the first party in a readilyoperated condition after the second party's period expires. ${ }^{24}$

Budi Santoso also gives a similar definition, which is an agreement between the Government as a project owner with another party as an operator. ${ }^{25}$ The Government gives right to other parties to build and operate facilities in a certain period while

\footnotetext{
${ }^{20}$ Maria S.W. Sumardjono. (2008). Tanah Dalam Perspektif Hak Ekonomi Sosial dan Budaya. Jakarta: Penerbit Buku Kompas. p. 208.

${ }^{21}$ Urip Santoso. (2013). Penggunaan Tanah Hak Pengelolaan Oleh Pihak Ketiga. Jurnal Dinamika Hukum, 13.2, 283-292, p.287.

22 Ibid.

${ }^{23}$ Maria SW Sumardjono. (2007). Hak Pengelolaan: Perkembangan, Regulasi, dan Implementasinya, Jurnal Mimbar Hukum Edisi Khusus. p. 150.

24 Ibid.

${ }^{25}$ Budi Santoso. (2008). Aspek Hukum Pembiayaan Proyek Infrastruktur Dengan Model Built, Operate, and Transfer, (Yogyakarta: Genta Press, 2008), p. 15- 16.
} 
taking a part or whole profit and when the agreed period has expired, he or she must return the facilities to the Government as the Project Owner. ${ }^{26}$

The definition of BOT can also be analysed from the definition of Buildings for Distribution as regulated in Government Regulation No. 28 of 2020 concerning Changes of Government Regulation No. 27 of 2014 concerning State-Owned or LocalOwned Item Management. In the regulation's first Article, it has been set that what is meant by Buildings for Distribution is the Utilization of State-Owned or Local-Owned Items in the form of lands by other parties by bulding structures and/or facilities, then is used by the corresponding party within an agreed period, for the lands and the buildings and/or facilities are to be given back after the period expires.

Land Use Agreement and BOT are indeed one of the terms that must be fulfilled if there is a Third Party that wants to use the land, but those are not the only ones that must be done. The corresponding third party must also ask for the holder's recommendation which is then forwarded by asking for permission to grant the right to the Head of District/City Land Office whose working area includes the corresponding land. If the request is granted, then the corresponding Head of District/City Land Office will publish a Right Distribution Decision Letter (SKPH) that will be given to the applicant. The letter must be registered to a local District/City Land Office to get a desired Land Right Cerfiticate that will be useful as an evidence for the holder (the corresponding third party).

There are several types of land rights that can be given on the land according to existing regulations, which are:

- Agrarian Minister Regulation 9/1965 Article 6: Use Right

- Minister of National Affairs Regulation No. 5 Of 1974 Article 5 verse (7): Ownership Right, Building Right, and Use right upon a plot of land.

- Minister of National Affairs Regulation No. 1 Of 1977 Article 2: Ownership Right, Building Right, and Use right upon a plot of land.

- Agrarian Minister/Head of National Land Agency Regulation No. 4 of 1998 concerning Guidelines in Establishing Income in Giving State Land Right: Ownership Right, Use Right, and Building Right upon a plot of land.

- Government Regulation 18/2021 Articles 2, 36, and 51: Cultivating Right, Building Right, and Use Right upon a plot of land.

From some existing regulations, some land rights may be established on the Management Right lands, which are:

- Ownership Right

- Cultivating Right

- Building Right

- Use Right

\subsection{Ownership Right}

Basic Agrarian Law Article 20 verse (1) defines Ownership Right, which is a hereditary, the strongest, and the most complete right that someone can have of land. Urip Santoso defines "hereditary" as a Land Ownership Right that can continuously go

\footnotetext{
${ }^{26} / \mathrm{bid}$.
} 
on as long as the owner is alive and if the owner is deceased, then it can be continued to his or her heir, as long as the heir fulfils the terms as an Ownership Right subject. "The Strongest" means that the right is more powerful than other land ownership rights, easily maintained from other parties' distractions and cannot be easily removed. "The Most Complete" means that this right gives its holder the widest authorize, compared to other land rights, can be a parent for other land rights, but not parenting other land rights. ${ }^{27}$

The subjects of Ownership Right are regulated in the Basic Agrarian Law Article 21:

- Indonesian citizens;

- Legal entities established by the Government, based on the Government Regulation No. 38 Of 1963 Article 1 concerning the Appointment of Legal Entities that May Have Land Ownership Right, which are: The State's bank, religious entity, social entity, and agricultural cooperative.

In fact, Ownership Right cannot be given on the Management Right land. This is because there is a uniqueness that sticks to this right which is reflected from its characteristics. One of them is hereditary, which indirectly indicates that this right does not have a specific period. This is against the Management Right which has a definitive period. It is impossible that something that has an indefinite period adheres to something that has a definitive period.

If there is a third party that wishes to use a part of the land, then the necessary legal action is not making Land Use Agreement/ BOT, but it must be done by the land's relegation by the holder. This can only be done after there is an agreement between the future Ownership Right holder and Management Right holder concerning the refund that needs to be paid.

Based on Agrarian Minister/Head of National Land Agency Decision No. 21 of 1994 Article 1 No. 3 concerning Guidelines to Own Lands for Corporations in terms of investation related to the Government Regulation No. 36 of 2005 Article 1 No. 6 concerning Land Creation for Building Executions for Public Needs, what is referred as Land Ownership Right Relegation is an action to relegate legal correlation between land right holder with the land he or she owns by giving refund as discussed.

Management Right Relegation can be done through declaration of relegation letter or distributing the land by the holder or with relegation deed or distribution of the land by a notary. However, if the referred land is owned by either Provincial or District/City Government, then according to the guidelines of Act No. 1 of 2004 Article 45 verse (2) and Article 48 verse (1) concerning State Treasury related to the Government Regulation No. 6 of 2006 Article 46 verse (2) and Article 47 verse (2) concerning State-Owned or Local-Owned Item Management, the making of the relegation deed must be proceeded by an agreement from the Head of Provincial House of Representative and/or corresponding Governor or Regent/Major.

The juridical consequence of the corresponding land relegation is the severed legal correlation between the land right holder and his or her owned land. Despite that, it will not cause a direct right transfer to the future ownership right holder, but

\footnotetext{
${ }^{27}$ Urip Santoso, Hak Atas Tanah, Hak Pengelolaan \& Hak Milik atas Satuan Rumah Susun, (Jakarta: Kencana, 2017), p. 19 (Urip Santoso IV).
} 
the lad will be owned directly by the State. After it becomes the State's land, the corresponding third party can then apply for a permission to obtain ownership right on the State's ex-Management Right land to a local Head of District/City Land Office.

\subsection{Cultivating Right}

Cultivating Right (HGU) is the right to cultivate the land owned directly by the State for agriculture, gardening, fishery, or stockbreeding. Cultivating Right is limited to maximum 35 ofs, which can later be extended by maximum 25 ofs. Law subjects that may have this right are Indonesian citizens and Indonesian legal entities.

Cultivating Right cannot be adhered on the Management Right land. It is because the Basic Agrarian Law has strictly decided that this right can only stick to the lands directly owned by the State. This means that whatever requirements which levels are below the law that regulates that Cultivating Right can adhere on the land is a rule against the Basic Agrarian Law, and the rule can be put aside consequently.

\subsection{Building Right and Use Right}

Building Right (HGB) is the right to build and own a building on the land that he or she does not own. The subjects of this right are Indonesian citizens and Indonesian legal entities. Based on the Government Regulation No. 18 of 2021 Article 36, this right can adhere to the State's Land, Management Right Land, and Ownership Right land. The period of this right on the Management Right Land is maximum 30 ofs which can be extended by 20 ofs and can be renewed by maximum 30 ofs. (Refer to the Government Regulation No. 18 of 2021 Article 37 verse (1)).

Use Right is defined as a right to use and/or to collect products from the directlyowned State's land or other people's land. The word "use" means this right is used to build structures, while the word "collect" means this right is used for other needs beside building structures, such as agriculture, gardening, fishery, and stockbreeding. ${ }^{28}$

Subjects of this right are:

- Indonesian citizens;

- Legal entities which are established based on Indonesian laws and are located in Indonesia;

- Department, non-departmental government institution, and Local Government;

- Religious and social entities;

- Foreigners who reside in Indonesia;

- Foreign Legal Entities which have representatives in Indonesia;

- Foreign and international entities' representatives.

Use Right on the land may be given with the first period of maximum 25 ofs, and can be extended to maximum 20 ofs, and can be renewed for maximum 25 ofs.

Building Right and Use Right can be given on the Management Right land, but there are several important things that need to be paid attention related to that. First is the distribution of this right can only be done if proceeded by the writing of Land Use Agreement/BOT between the corresponding third party and the Management Right holder. It must be followed up by a recommendation from the holder. The next thing

\footnotetext{
${ }^{28}$ /bid., p.99.
} 
the corresponding third party must do is applying a permission to grant Building Right or Use Right to the Head of District/City Land Office whose working area includes the corresponding land. After the permission is granted, then a Decision Letter to Grant Building Right or Use Right upon Management Right Land, which must be registered to local District/City Land Office. The registration will later result in Building Right or Use Right upon Management Right Land Certificate that can be an evidence that the right is owned by the corresponding third party.

If the Building Right or Use Right holder of the land want to extend, renew, transfer, or assess the right of the corresponding land, then he or she must obtain the agreement of the Management Right holder first. If the Building Right or Use Right of the land becomes an object for land creation, then the one who has the right to claim refund is the Building Right or Use Right holder for his or her buildings and the Management Right holder for his or her land.

\section{Conclusion}

Based on the elaboration above it can be concluded that there are two types of Land Rights that can be given on the land, which are Building Right and Use Right. Ownership Right cannot be given on the land because it is restricted by the nature that sticks with it, while Cultivating Right cannot be given on the land because based on its definition that is explained in the Basic Agrarian Law, Cultivating Right can only stick to the land owned directly by the State (the State's land).

\section{References}

\section{Journals:}

[1] Eman Ramelan. (2000). Hak Pengelolaan Setelah Berlakunya Peraturan Menteri Negara Agraria/Kepala Badan pertanahan Nasional". Majalah YURIDIKA, 15.3

[2] Maria S.W. Sumardjono. (2007). "Hak Pengelolaan: Perkembangan, Regulasi, dan Implementasinya". (2007). Jurnal Mimbar Hukum Edisi Khusus, Fakultas Hukum Universitas Gadjah Mada. Yogyakarta.

[3] Urip Santoso. (2012). Eksistensi Hak Pengelolaan dalam Hukum Tanah Nasional. Jurnal Mimbar Hukum, 24.2, 187 - 375.

[4] Urip Santoso. (2013). Penggunaan Tanah Hak Pengelolaan Oleh Pihak Ketiga. Jurnal Dinamika Hukum, 13.2, 283-292.

\section{Books:}

[1] A.P. Parlindungan. (1994). Hak Pengelolaan Menurut Sistem Undang-Undang Pokok Agraria. Bandung. Mandar Maju.

[2] Boedi Harsono. (2013). Hukum Agraria Indonesia: Sejarah Pembentukkan Undang-Undang Pokok Agraria, Isi dan Pelaksanaannya. Jakarta. Djambatan.

[3] Budi Santoso. (2008). Aspek Hukum Pembiayaan Proyek Infrastruktur Dengan Model Built, Operate, \& Transfer. Yogyakarta. Genta Press.

[4] Maria S.W. Sumardjono. (2008). Tanah Dalam Perspektif Hak Ekonomi Sosial dan Budaya. Jakarta. Penerbit Buku Kompas. 
[5] Muhammad Bakri. (2007). Hak Menguasai Tanah Oleh Negara (Paradigma Baru untuk Reformasi Agraria). Jakarta. Citra Media.

[6] Peter Mahmud Marzuki. (2017). Penelitian Hukum. Jakarta. Kencana.

[7] Urip Santoso. (2017). Hak Atas Tanah, Hak Pengelolaan \& Hak Milik atas Satuan Rumah Susun. Jakarta. Kencana.

[8] Urip Santoso. (2017). Hukum Agraria Kajian Komprehensif. Jakarta. Kencana.

[9] Urip Santoso. (2019). Pendaftaran dan Peralihan Hak atas Tanah. Jakarta. Kencana.

[10] Yudha Bhakti Ardhiwisastra. (2012). Penafsiran dan Konstruksi Hukum. Bandung. PT.Alumni. 